Jap. J. Psychol.,

1972, Vol. 43, No. 5, 238-250.

\title{
政治的社会化過程に称ける〈政治的知識〉 と〈政治的態度〉の関連
}

\author{
東 京大学 \\ 広瀬弘忠 ${ }^{1}$
}

政治意識の形成がぞのような過程を経て行なわれそ の変容がぞのようにして起こるかという問題に答えうる ためには，政治的社会化の諸研究に目を兑ける必要があ る (広瀬, 1971)。1950 年代後半から 60 年代前半にかけ て, 政治的発達, とくに子供之青年の政治的発達につい ての調查が行なわれるようになり，この時期に Hyman （1959）にならって政治的社会化といら言葉がこの種の 調査に使われるようになった。 (Greenstein，1968)

政治的社会化は, 広い意味では, 社会が世代から世代 へ政治的文化を伝達する栐式で㐫り，この過程は伝統的 政治規範の保存と 2 次的社会化の機関（学校・同輩集団 など）による規範の変容を含んでいる，他方，政治的社 会化は個人の観点からみれば，政治的諸価值の内面化の 過程であり, 政治的行動様式, 政治的態度などの学習過 程で方る. (Hyman，1959)

政治意識の研究がすすむにつれ，さまざまの政治的態 度が子供の頃に獲得され，成人後る保持されることがあ きらかとなってきたが，これは政治的社会化の保守的機

1 本研究の資料は日本コンサルタントグループの堀正 幸氏が物こなった調査によって作成されたものです。原 資料を和借しくださいました同氏と, 有益な御教示をい ただきむした東京大学の池内一教授に, 深く感謝いたし 屯于.

2 政治事象索ながめる際に，もっとも主要な態度次元 のひとつが, 保守一革新であるとする, 多くの研究報告 がある、たと壳ば，田中国夫(1964 日本人の社会的態度, 誠信書房) は Eysenck (1954, Psychology of Politics, Routledge \& Kegan Paul Ltd.) の調査を追試した結 果, 日本人の政治的態度の中にも, 保守一革新の次元が 存在することを確認している。京極純一（1962 政治的 イメージの測定について, 東京大学教養学部社会科学 紀要, Pp. 1-52). 飽戸 弘 (1970 イメージの心理学, 潮出版), 広瀬弘忠 (1971 政党支持々政治関心の構造分 析 心研，42，175-184）などは，政治事象を保守一革 新の次元でみるという制度が，われわれの社会に定着し ている事実をあきらかにしている。
能を示するのであり，また，青年は大人の行動を拒否す ることによって, 自分達を大人とは違ったるのにしょう そする.これは政治的社会化の革新的機能を示するのと いうことができる.

Hyman (1959) 㳊治的社会化の主要な様式のひとつ として政治志向 (Political orientation)をとりあげて いる，彼はこの言葉を十分限定された意味で使ってはい ないが，彼の趽こなった分析によって知るかぎり，これ は “政治的態度の方向づけ”之 “政治的知識の分化” の 両方を含んでいるょうである. Easton \& Hess (1961) は Hyman の立場を発展させ, 政治志向第 1 亿, 政治 事象索認識する手段としての知識, 第 2 亿, 認識された 政治事象を判断する枠組としての洒值, 第 3 亿, 判断の 結果生じる態度の 3 つの構成要素に分け, 各々の分化と 方向づけを考光ている. しかし，このうち 2 番目の政治 的価值の形成については，これが政治的態度の方向つけ と密接し, 両者を操作的に分離することの困難な点など を考慮して，ここでは前者学後者に組み入れ，政治志向 を知識と態度 ${ }^{2}$ (政治志向の態度成分は保守一革新の程 度を意味する：直井，1972）として考觉ることにする。

政治志向は個人の発達の早い時期に芽ば学もつ.ア メリカでは学令前の子供でも, 大統領, 警察, 国旗につい ての概念をもっているし，9才までに 2 大政党に対する はっきりした好みをるつようになる。 (Easton \& Hess， 1961). そして，政治志向は年令とともに分化し，10才 以前では分化の程度は低いが，高校 1 年になるとかなり 高くなる. (Hyman, 1959)

ここで, 政治的社会化の機関に注目してみよう. 小学 校 5 年から中学 3 年へと進む過程で, 1 次的な機関（家 庭）の影響力は相対的に小さくなり，2 次的な機関（学 校・同輩集団）の影響力が大きくなる. この影響のもと で, 青年期に特有の態度招よび行動のパターンがうみだ される. (Sears, 1969) 学校に特ける政治教育の意義が さまざまの方向から論じられるゆえんである。

アメリカの政治教育は公式的, 図式的で, 政治のダイ 
ナミクスよりも機椣の説明に重点が拈かれている. (Greenstein, 1968) 日本でも事態は同じであるが, 以 下やや詳しく，日本の政治教育の実態を述べて特こう.

小学校の “社会科”では人間関係を身近かな小さな集 団から，次第に大きな集団へと，同心円的に拡大してゆ く、6年生になるにいたって, “民主主義” “平和”とい ら言葉とともに，“日本の政治” “日本の歴史” “世界との 親善”が教えられ, “話しあいによる政治”“代表者の選 出” “多数決と小数者の意見”などが学ばれる。これに附 随する機構として “国会” “選挙” “政党” “世論” “内閣” “裁判所”“三権分立” “日本国憲法”などが教えられる。 中学校では，1年で“地理”，2年で“歴史”をそれぞ れ日本と世界について学び, 3 年で “政治・経済・社会” を学習する。この“政治・経済・社会”では, “民主主 義の精神” 学欧米社会に範を字をめて解説し, “平和国 家”としての日本の姿を述べている. また, 政治機構に ついては，憲法を軸として“国会”“世論”なとについ て, 詳しく解説している. 小学校以来の小さい集団から 同心円的に拡大される“政治のしくみ”と中学 3 年で教 えられる “政治・経済・社会”との間には質的な違いが ある.

高校全日制の課程では，3年で “政治・経済” 履習 することになっている。ここでは，“日本の政治” “日本 の経済” “労働問題と社会福祉” “国際関係之国際協力” が単元をなしている. 高校 3 年の “政治・経済”では, 中学 3 年の “政治・経済・社会”を受けついでいるが, 建前のみならず, 現実の記述と批判にも重点が和かれて いる.（岡村・相内・北岡・崔・迫川, 1969）

\section{問題}

本研究の主題は政治志向の主成分である, 政治的知識 と政治的態度が，政治的社会化の過程で互いにどのよう な関連をもっているか吟味することにある.

そのために，第 1 ，青年期にある人々をとりあげ，第 2 , これらの人々に政治的知識の分化の程度と, 政治的態 度の方向づけの程度を確定する調查を行ない, 第 3 , 得 られたデータに数理モデルを適用することによって, 両 者の関係をさぐる.以上 3 段階の手順をらむことになる. そのとき，次の 2 点汇配慮すべきであろう，第 1 , 政治 的知識についての質問は，現在政治的イシューとなって いる事象についてたずねるものであることがのぞまし いなぜなら，その時々の政治的イシュ一に対する知識 量は, 学校その他で教えられる知識と異なり, 修学年数 の影響を受けにくく，その時点での意四的な政治的知識 の獲得速度をあらわすと考えられるからである。第 2, 政治的態度についての質問も，現実のホットな政治的イ シューについての態度をきくものの汪うがよい， ステレ オタイプ化した反応をある程度さけることができるから
TABLE 1

調查 対 象

\begin{tabular}{|c|c|c|c|c|c|}
\hline 学 & 校 & 学 年 & 男 & 女 & 合 \\
\hline 中 & 学 & 3(年) & 62 & 51 & 113 \\
\hline \multirow{3}{*}{ 高 } & \multirow{3}{*}{ 校 } & 1 & 58 & 22 & 80 \\
\hline & & 2 & 87 & 0 & 87 \\
\hline & & 3 & 27 & 10 & 37 \\
\hline & \multirow{4}{*}{ 学 } & 1 & 81 & 19 & 100 \\
\hline & & 2 & 86 & 17 & 103 \\
\hline & & 3 & 7 & 6 & 13 \\
\hline & & 4 & 8 & 2 & 10 \\
\hline \multicolumn{2}{|c|}{ 合 } & 計 & 416 & 127 & 543 \\
\hline
\end{tabular}

である。

\section{調 查}

調査対象 長野県下の中学・高校の男女生徒と信州大 学の男女学生. らちわ壮は Table 1 に示されると特り である，男女間には，若干の程度の差があるとしてる， 実際の傾向は類似して特り，かつ，女子の数が少ないと ころから, 分析の際には, 男女はこみにされ, 性差は無 視される。また，大学の 3 年， 4 年の学生間には汪とん ぞ差がなく, 数が少ないところから，これらは合併され て, 大学 $3 \cdot 4$ 年といらグループをつくる.

調査時点 1970 年 12 月

調查方法 集団面接法

\section{調查変数の構造}

I 知識項目 各間々も正解を含む 4 つの反応カテゴ リーのなかから1つを選択する。

（1）安保・自衛隊についての知識をきく質問群

1. 第 1 次安保条約成立 2 . その時の首相名 3 . 自動 延長 4 . 自衛隊の指揮権 5 . 現在の防衛庁長官名 6.4 次防 5 力年計画

（2）憲法・労働邁動・沖繩問題についての知識をき 質間群

1. 日本国憲法第 9 条の規定 2. 総俨 3. 沖繩返還の 時期 4. 核奴き本土並又返還 5. 潜在主権 6. 沖繩 の人口

（3）日本の政治・経済・外交についての知識をきく 質間群

1. 非武装中立 2. 日本の国民総生産 3. 一人市たりの 国民所得 4. 大蔵大臣名 $5.3 \mathrm{C} \quad 9$. 経団連 7. 所得 倍增政策 8 . 自ら国を守る気概をもて 9 . 外務大臣名 (4) アメリカの政治・経済

1. バイアメリカン・シップアメリカン 2 . 黒人の公 民権運動 3. グアムドクトリン 4. アメリカの大統領 名 5.2 大政党名 6 . 貿易の自由化

（5）アメリカの軍事・外交 
1. 第 7 艦隊所属国 2. 新孤立主義外交 3. ヴェトナ ム化政策 4. 駐日アメリカ大使名 5 . アジア安保

II 態度項目 各間とも, “非常飞賛成”“ぞちらかと いえば賛成”“どちらともいえない”“どちらかとい党ば 反対” “非常に反対”のなかから 1 つの反応カテゴリー を選択する。

（1）安保・自衛隊についての態度をきく質開群

1. 安保の特かげ 2. 安保は役立つ 3. 自衛隊は憲法 違反 4. 自衛隊強化 5 . アメリカの日本防衛 6 . 安保 は共産主義国に脅威 7 . 安保

（2）アメリカの軍事・外交についての態度をきく質 問群

1. アメリカのヴェトナム撤退 2. アメリカの対外援 助減 3.アメリカ軍隊のアジア・ヨーロッパからの撤退 4. ヴェトナム戦争はアメリカの敗北 5.ヴェトナム戦争

（3）アメリカの政治・経済についての態度をきく質 問群

1.アメリカの保護貿易政策 2.アメリカの経済的困 察

（4）日本の政治・経済・外交についての態度をきく 質問群

1. 共産主義国との平和条約 2 . 経済成長 3. 経済 成長は政治の拉かげ 4. 経济成長は国民勤勉の括かげ 5. 経済成長は労働者の生活を犠牲にしたため 6. 経済 成長は軍事予算を最小限にとどめたため 7 . 経済成長は 教育水準が高いから8. 企業は東南アジアに進出すべき 9. 貿易の自由化 10. 経済大国日本 11 . 将来の日本 経済のゆきづまり 12 . 日本独自の外交政策の必要性

（5）沖繩・平和運動についての態度をきく質問群

1. 黒人の公民権要求 2 . アメリカの反戦運動のたか ※り 3. 平和の国アメリカ 4. 沖繩返還 5. 核兵器 残留での沖繩返還

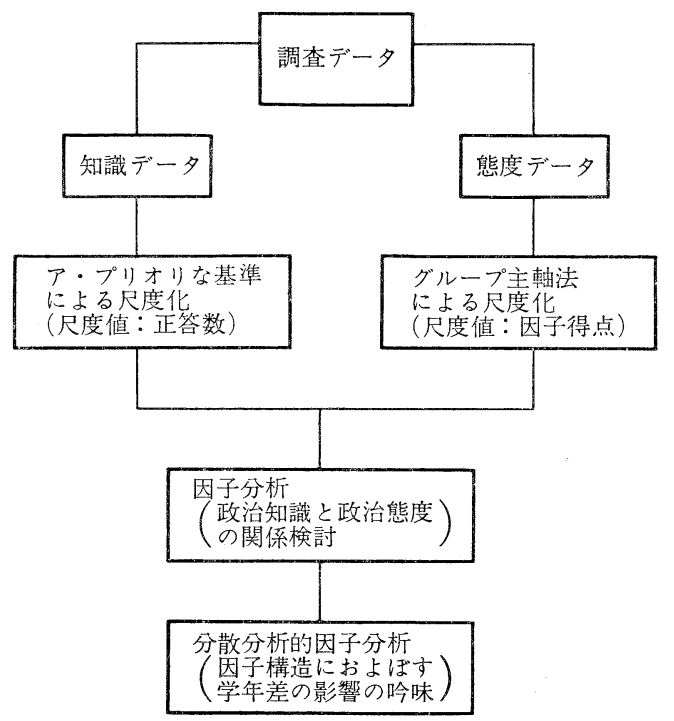

FIG. 1. 分析のためのフローチャート
（6）日本の軍国主義についての態度をきく質問群

1. 日本が侵略される叔それ 2. 太平洋戦争は賁南つ ジアの人々を助けた 3 . 日本の徵兵制 4 . 小型核兵器 の所有可能性 5 . 核兵器所有の必要性 6 . 日本はアシ アの指導者 7. 日本は，末た軍国主義に多どった 8. 天皇起愛し尊敬する心が必要 9 . 自主防衛の必要性な どであるが，詳しくは附表を参照されたい。

結果

\section{結果の整理}

尺度の構成 調査結果は Fig. 1 に示される手順で整 理された。 まず，調査データをカード化した後，32 項 目の知識変数から<調査変数の構造 >で示される基準に よって 5 つの知識尺度が構成され，尺度内の正答数をも って各個人の尺度值とした。

態度尺度の方は構造がやや複雑で, 一応の分類はある ものの, 変数が意味のらえで相互に重なりあったり, い くつかの尺度に重複して属したりしている.そこで, グ ループ主朝法 (Horst, 1965 ; 芝, 1967) を使用して尺 度構成を持こなった. はじめに，＜調査変数の構造〉で 示された仮の尺度をるらいて分析し， 尺度外変数でしか も尺度合成变量と高い相関を示するのは尺度内にとり入 れ, 逆に, 尺度内变数であっても因子負荷の小さいもの は尺度外に出し, また, 信頼性を高めるため尺度を合併 乙, 試行錯䛊的に前後 4 回の計算を経て構成されたのが Table 2 の 4 つの尺度である. 各尺度について, 重みが 0 以外の変数が尺度項目である. いくつかの変数は $2 つ$ の尺度に重複して属しているので, 尺度間の相関を高め る結果になっているが，ある变数を別々の尺度に同時に とり入れなければならないといらことは，もともとの尺 度間の相関が高いことを意味する. ここでは変数を重複 してとることによる損失よりあ，信頼性を高めることに よってもたらされる利益の方が大さいと考えた。

信頼性の下限を与える $\alpha$ 係数 (Lord \& Novic, 1968) によって，これらの尺度の安定性をみると，Table 2 に 示されるように“安保・自衛隊・軍国主義”尺度, 0.813 : “アメリカの政治・経済・外交・軍事”尺度, 0.717 : “日本の政治・経済・外交”尺度, 0.603 : “平和 運動・沖繩問題” 尺度, 0.466 ではじめの 2 つの尺度の 安定性は良好だが，おの 2 つの尺度は若干劣る。特に， “平和運動・沖繩問題”尺度は $\alpha$ 係数が低いが，これは 尺度内に含まれる変数の数が少ないためである゙。

$3 \alpha$ 係数は $\alpha_{P}=\left(\frac{n}{n-1}\right)\left(1-\frac{1}{\lambda_{P}}\right)$

$\left(n\right.$ : 変数の数, $\lambda_{P}:$ 第 $P$ 因子の固有値 $)$

固有值の大きさは, 一般に变数の数が増すにつれて大 きくなる、すると， $\alpha_{P}$ の值はこれにつれて大きくなる ことがわかる。（浅野長一郎 1971 因子分析法通論 共 立出版) 
TABLE 2

政治的態度尺度構成のためのグループ主軸法の結果

\begin{tabular}{|c|c|c|c|c|c|c|c|c|c|}
\hline \multirow[b]{2}{*}{ 変 } & \multirow[b]{2}{*}{ 数 } & \multicolumn{2}{|c|}{$\begin{array}{l}\text { 安保・自徫隊・ } \\
\text { 軍国主義 }\end{array}$} & \multicolumn{2}{|c|}{$\begin{array}{l}\text { アメリカの政治・ } \\
\text { 経済・外交・軍事 }\end{array}$} & \multicolumn{2}{|c|}{$\begin{array}{l}\text { 日本の政治・経 } \\
\text { 済・外交 }\end{array}$} & \multicolumn{2}{|c|}{$\begin{array}{l}\text { 平和運動・沖繩 } \\
\text { 問題 }\end{array}$} \\
\hline & & $\begin{array}{l}\text { 構造べ } \\
ク ト ル ~\end{array}$ & 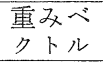 & $\begin{array}{l}\text { 構造べ } \\
ク ト ル ~\end{array}$ & 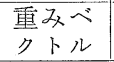 & $\begin{array}{l}\text { 構造べ } \\
ク ト ル ~\end{array}$ & $\begin{array}{l}\text { 重み心゙ } \\
\text { クトル }\end{array}$ & 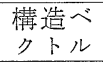 & $\begin{array}{l}\text { 重みベ } \\
ク ト ル ~\end{array}$ \\
\hline 1 & か & .762 & .182 & .804 & .285 & .366 & .000 & .274 & .000 \\
\hline 2 & 安 & .700 & .167 & .791 & .280 & .300 & .000 & .244 & .000 \\
\hline 3 & 自 衛 隊 憲 法 違 反 $(\mathrm{R}) \dagger$ & .566 & .135 & .447 & .000 & .249 & .000 & .152 & .000 \\
\hline 4 & 自 & .652 & .155 & .460 & .000 & .299 & .000 & .215 & .000 \\
\hline 5 & 太平洋戦争は東アの人々を助けた & .474 & .113 & .297 & .000 & .321 & .000 & .172 & .000 \\
\hline 6 & 日本侵略の拈それ & .252 & .060 & .152 & .000 & .096 & .000 & .083 & .000 \\
\hline 7 & 防 & .551 & .131 & .473 & .000 & .366 & .000 & .182 & .000 \\
\hline 8 & 安保は共産諸国に脅威 & .228 & .054 & .230 & .000 & .049 & .000 & .098 & .000 \\
\hline 9 & 共産諸国との平和条約 & -.245 & .000 & -.256 & .000 & -.054 & .000 & -.231 & .000 \\
\hline 10 & 安 & .793 & .189 & .844 & .299 & .404 & .000 & .332 & .000 \\
\hline 11 & 米軍の ヴェトナム撤退 & .097 & .000 & .154 & .055 & .157 & .000 & -.099 & .000 \\
\hline 12 & 米 $の$ 外 国 援 助, 減 (R) & .086 & .000 & .146 & .052 & .014 & .000 & -.045 & .000 \\
\hline 13 & 米の保 護 貿易 政策 (R) & .114 & .000 & .204 & .072 & .070 & .000 & .014 & .000 \\
\hline 14 & 黒人の公民権 要 求 (R) & .151 & .000 & .156 & .000 & .026 & .000 & .667 & .408 \\
\hline & 米の反戦 運 動, 増 ( $\mathrm{R})$ & .110 & .000 & .162 & .000 & .139 & .000 & .554 & .339 \\
\hline 16 & $\begin{array}{l}\text { 米以アジア・ヨーロッパから軍隊 } \\
\text { 撤退すべき }(\mathrm{R})\end{array}$ & .323 & .000 & .513 & .182 & .151 & .000 & .703 & .430 \\
\hline 17 & ヴェトナム戦争は米の敗北 （R） & .399 & .000 & .583 & .207 & .242 & .000 & .162 & .000 \\
\hline 18 & トナ ム 戦 争 & .200 & .000 & .321 & .114 & .102 & .000 & .332 & .000 \\
\hline 19 & 米 の 経済的困窮 (R) & .113 & .000 & .207 & .073 & .144 & .000 & .045 & .000 \\
\hline 20 & 平和な国アメリカ & .311 & .000 & 32 & • & .282 & .000 & .382 & .233 \\
\hline 21 & 日 本 の 経 済 成 長 期 & .267 & .000 & .193 & .0 & .456 & .207 & .019 & .000 \\
\hline 22 & 経済的成長は政治の捛かげ & .417 & .000 & .404 & .000 & .535 & .242 & .254 & .000 \\
\hline 23 & 経済的成長は国民の勤勉の叔かげ & .150 & .000 & .086 & .000 & .535 & .242 & -.020 & .000 \\
\hline 24 & 経 済成 長 の為学働者生活け & .270 & .000 & .296 & .000 & .349 & .158 & .272 & .000 \\
\hline 25 & 経済成長は軍備予算最小化のため & .258 & .000 & .236 & .000 & .575 & .26 & .112 & .000 \\
\hline 26 & 経済成長は教育水準の执かげ & .139 & .00 & .111 & .0 & .577 & .26 & -.007 & .000 \\
\hline 27 & 日本企業の東南アジア進出期待 & .472 & .000 & .377 & .000 & .542 & .24 & .032 & .000 \\
\hline 28 & 自由 由 & .015 & .000 & -.015 & .000 & .321 & .14 & -.074 & .000 \\
\hline 29 & 大国，日 & .131 & .000 & .083 & .000 & .350 & .159 & .066 & .000 \\
\hline 30 & 日本経済の将来ゆきづまり & .106 & .000 & .149 & .000 & .349 & .158 & .173 & .000 \\
\hline 31 & 沖 & .036 & .000 & .065 & .000 & -.086 & .000 & .385 & .235 \\
\hline 32 & 核兵器残留での沖繩返還 & .087 & .000 & .053 & .000 & -.008 & .000 & .309 & .189 \\
\hline 33 & 本 の & .101 & .024 & -.007 & .000 & .036 & .000 & .151 & .000 \\
\hline & 日本, 小型核兵器所有可能性 & .429 & .102 & .211 & .000 & .125 & .000 & .193 & .000 \\
\hline 35 & 日本の核兵器所有の必要性 & .553 & .132 & .317 & .000 & .169 & .00 & .207 & .000 \\
\hline 36 & 日 本, アジアの指導者 & .422 & .100 & .241 & .000 & .340 & .000 & .066 & .000 \\
\hline 37 & 日本独自の外交政策の必要 & -.088 & .000 & -.189 & .000 & .040 & .000 & -.190 & .000 \\
\hline 38 & 日 本 の 軍国主義 復 活 & -.354 & -.084 & -.327 & .000 & -.245 & .000 & -.039 & .000 \\
\hline 39 & 天皇老愛し尊敬する心が必要 & .444 & .106 & .283 & .000 & .248 & .000 & .155 & .000 \\
\hline & 自国の自主防衛の必要性 & .336 & .080 & .132 & .000 & .158 & .000 & -.030 & .000 \\
\hline & 教 & & & & & & & & \\
\hline
\end{tabular}

†因子スコアが $(+)$ 革新 (一) 保守になるよう（R）のついた変数はスコアリングを逆向きにしてある 
TABLE 3

尺度間の相関係数

\begin{tabular}{|c|c|c|c|c|c|c|c|c|c|c|}
\hline & \multicolumn{3}{|c|}{ 知 } & \multicolumn{2}{|l|}{ 識 } & \multicolumn{2}{|c|}{ 態 } & \multicolumn{2}{|c|}{ 度 } \\
\hline & & $\begin{array}{l}\text { 安保・ } \\
\text { 自衛隊 }\end{array}$ & $\begin{array}{l}\text { 憲法・ } \\
\text { 労働運 } \\
\text { 動・沖 } \\
\text { 繩問題 }\end{array}$ & $\begin{array}{l}\text { 日本の } \\
\text { 政治・ } \\
\text { 経済・ } \\
\text { 外交 }\end{array}$ & $\begin{array}{l}\text { アメリ } \\
\text { カの政 } \\
\text { 治・経 } \\
\text { 済 }\end{array}$ & $\begin{array}{l}\text { アメリ } \\
\text { カの軍 } \\
\text { 事・外 } \\
\text { 交 }\end{array}$ & $\begin{array}{l}\text { 安保・ } \\
\text { 自 衛 } \\
\text { 豚・軍 } \\
\text { 国主義 }\end{array}$ & $\begin{array}{l}\text { アメリカ } \\
\text { の政治 } \\
\text { ・経済・ } \\
\text { 外交・ } \\
\text { 軍事 }\end{array}$ & $\begin{array}{l}\text { 日本の } \\
\text { 政治・ } \\
\text { 経済・ } \\
\text { 外交 }\end{array}$ & $\begin{array}{l}\text { 沖繩問 } \\
\text { 題 - 议 } \\
\text { 和運勤 }\end{array}$ \\
\hline \multirow{3}{*}{ 知 } & 安 保・自㦣隊 & 1.000 & & & & & & & & \\
\hline & 憲 法・労 働 運 動・沖 繩 問 題 & 0.372 & 1.000 & & & & & & & \\
\hline & 日 本 の 政 治・経 済・外 交 & 0.426 & 0.446 & 1.000 & & & & & & \\
\hline \multirow[t]{2}{*}{ 識 } & アメリカの 政 治・経 済 & 0.479 & 0.453 & 0.526 & 1.000 & & & & & \\
\hline & アメリカの 軍 事・外 交 & 0.371 & 0.369 & 0.405 & 0.535 & 1.000 & & & & \\
\hline \multirow{2}{*}{ 態 } & 安 保・自 衛 隊・軍国主義 & 0.267 & 0.246 & 0.401 & 0.288 & 0.293 & 1.000 & & & \\
\hline & アメリカの政治・経済・外交・軍事 & 0.248 & 0.235 & 0.346 & 0.248 & 0.272 & 0.841 & 1.000 & & \\
\hline \multirow[t]{2}{*}{ 度 } & 日 本 の 政 治・経 済・外 交 & 0.135 & 0.069 & 0.181 & 0.146 & 0.234 & 0.495 & 0.423 & 1.000 & \\
\hline & 沖 繩 問 題・平 和 運 動 & 0.088 & 0.038 & 0.114 & 0.072 & 0.072 & 0.335 & 0.442 & 0.166 & 1.000 \\
\hline
\end{tabular}

因子分析 知識尺度 5 つと態度尺度 4 つの合計 9 つの 尺度を因子分析し，知識と態度との関係を吟味する。

分散分析的因子分析 中学・高校 $\cdot$ 大学亡広い範团に わたる対象者を因子分析する場合，因子に発達的変動が 反映される場合がある、本研究の目的のひとつは, この 発達差をみようとすることであるから，発達差を含めた 変動の分析る必要であるが，同時に，発達差を除いた変 動を因子分析することによって, 発達によって影響され ない因子構造をもとめることる必要である。そこで, 学 年別に標準化を行ない, その結果をるらいて因子分析が 扣こなわれた。他方, 排除された学年差の変動も因子分 析され，学年差が，どのようにもとの因子構造に反映さ れていたかが吟味された.（Yanai，1970；柳井，1969； 芝, 1972)

\section{結果 I 政治的知識尺度と政治的態度尺度}

Table 3 に各尺度間の相関係数が示されている。この 表から, 総じて知識尺度内, 態度尺度内の相関の方が知 識・態度間の相関よりも大きいこと，これを具体的にい えば, 知識・態度間の同種の尺度, たとえば, “知識” の “安保・自衛隊”之“態度” の“安保・自衛隊・軍国 主義” の相関よりも, “知識” “態度” 内の概念的に近接 関係にある尺度，たと学ば，“知識”の“安保・自衛隊” と“日本の政治・経済・外交” の相関, “態度”の“安 保・自衛隊・軍国主義” と “アメリカの政治・経済・外 交・軍事”の間の相関の方が大きいことがわかる.

政治的知識の尺度別正答率を各学年について算出乙図 示したのが Fig. 2 である. この図によれば各尺度とも 推移の型は非常によく似ていることがわかる.ただ“ア メリカの軍事・外交”で正答率のレベルがやや括ちてい、 るが，これは，問題が若干むずかしかったせいである。
この図をこまかくみると，各尺度とも，高校 1 年でひ そつのピークを，高校 2 年で谷間をむかえている，義務 教育から解放され，広い世界に目が開かれていく高校 1 年生, 青年期のはじめにあたって彼らの政治事象に対す る知識欲も喚起されるのであろう。高校 2 年では, 高校 1 年の反動であろらか, 視野がせばまり, 知識欲も一時 減退する. もちろん, 別の解释も可能である。つ恋り, 後で若干られるように, 高校 1 年を, 発達段階のわりに, 政治的知識をるらすぎた特殊なグループと見ることもで きる.このように見て, 高校 1 年を除外して考觉れば, 中学 3 年と高校 2 年とは, 政治的知識の点ではほとんど

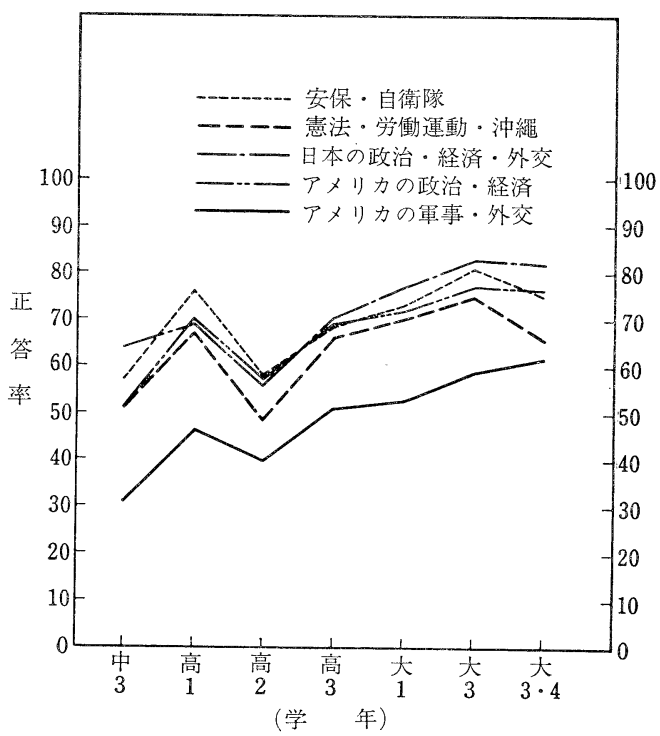

FIG. 2. 政治的知識の尺度別正答率 
差がなく、この間に, 顕著な政治的知識の獲得は特こな われなかったことになる．ふたつの解釈のうち，ぞらら が妥当であるかは，本報告のように発達段階ごとに異な 当個人をあつかった研究から確定できない。高校 3 年に なると，学校の教科で“政治・経済”を教兄られること も手伝って, 政治的知識の獲得が加速され, 以後, 大学 2 年末で直線的に上昇する。“アメリカの軍事・外交”を 除く各尺度では, 大学 $3 \cdot 4$ 年で知識獲得速度の滅衰が みら礼る. 大学生活慣孔, 専門課程の勉強と目前の就 職運動に忙殺される半社会人としての彼らの状沉を物語 っている.

以上要約すると, 青年期初期（中学 3 年一高校 2 年） では政治的知識の獲得は不安定で岕るが, 前期 (高校 3 年一大学 2 年) で恃安定し, 着実にのび, 中期(大学 3 ・ 4 年以降）にさしかかって減退のきざしが市らわれる。

尺度得点 (尺度内正答数) をもちいて一元配置の分散 分析を行ならと, “安保・自衛隊”, $F=21.86$, “囊法・労 㗢運動・沖繩”, $F=24.94$, “日本の政治・経済・外交”, $F=31.97, “ ア メ リ カ の$ 政治・経済”, $F=30.27, “ ア メ$ リカの軍事・外交”, $F=20.89$ で, いずれも $d f=(6,536)$, $F_{0.01}=2.85$ であるから，すべての尺度が $1 \%$ の有意水 準で有意である。つまり, 統計的に十分な確度で発達差 が認められる。

次に, Fig. 3 によって, 態度尺度の検討をしてみょ う. 一元配置の分散分析によって発達差を吟味すると, “安保・自衛隊・軍国主義”, $F=31.80$ “日本の政治・経 済・外交”, $F=10.08$, “アメリカの政治・経済・外交・ 軍事”, $F=22.48$, “沖繩問題・平和運動”, $F=1.43, d f$

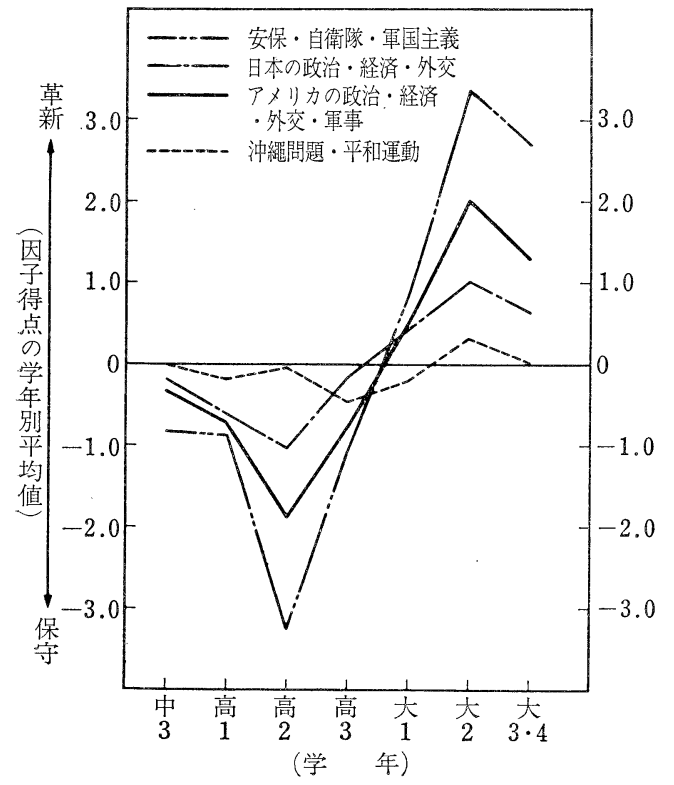

FIG. 3. 政治的態度の尺度別因子得点
TABLE 4

9 尺度の因子分析による因子負荷量 （主䎐解の後 2 因子によるバリマックス回転）

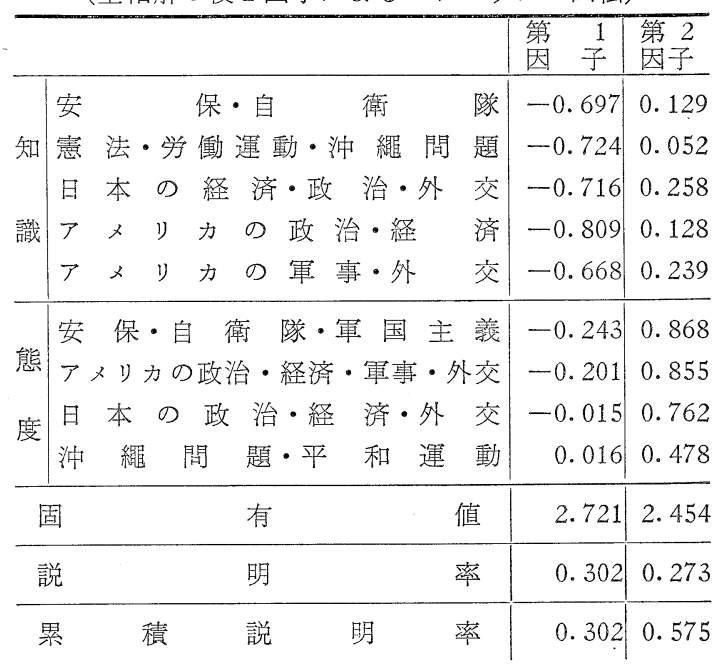

$=(6,536), F_{0.01}=2.85, \quad F_{0.05}=2.12$ であるから“沖繩 問題・平和運動”除く 3 尺度は, $1 \%$ の有意水準で有 意, “沖腎問題・平和運動”は，5\% でも有意ではない. したがって発達差を考光る際には，この尺度を除外して

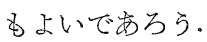

各尺度とも、汇 S 字形の推移を示している。“沖繩 問題・平和運動”を除いて考光れば, 中学 3 年生は, 保 守一革新連続体上のやや保守寄りに苟る。高校 1 年にな ると保守化はさらに進み，高校 2 年で保守のピークをむ か党るが, 高校 3 年, 大学 1 年と直線的な革新化の加速 が和こなわれ，大学 2 年で革新のピークがやってくる. 大学 $3 \cdot 4$ 年になると若干のゆりもぞしがあらわれる.

\section{結果 II 政治的知識と政治的態度の関連}

政治的知識 5 尺度, 政治的態度 4 尺度の, 合計 9 尺度 を用いて主軸法飞よる因子分析を物こない。固有值の動 さを不ると, Fig. 5 亿示されるように, 第 3 因子以降, 順次の固有值の差が急速に小さくなるので, 因子数を 2 因子とさだめる. 2 因子によるバリマックス回転を与光 たときの因子負荷量が Table 4 亿示されている. 第 1 因 子は全体の変動の $32.2 \%$ を説明している。知識尺度で は一貫して因子負荷が高く(總対值の意味で), 態度尺度 では相詨的に因子負荷が低くなっている.このことから 第 1 因子は知識因子だとい方る. 第 2 因子は説明率 27.3 \%で知識尺度への因子負荷が全体的に小さく, 態度尺度 への負荷が一貫して大きいので，態度因子であるといえ る. こ机ら両因子で全体の変動の $57.5 \%$ を説明してい る.

さて，第 1 , 第 2 因子からそれぞれ因子得点を推定す ると，第 1 因子の因子負荷量は全体的にマイナスで, と 
くに，知識尺度の負荷量はすべてマイナスであるから， 因子得点の大きいもの漂ど政治的知識が少なく，小さい もの汪ど政治的知識が有ることになる. そこで，第 1 因 子得点については，プラス，マイナスを逆にして，プラ ス二政治的知識有り，マイナス二政治的知識無しと方向 をそろえることにする。また，もともと態度尺度は保守 一革新度を測っているから，第 2 因子得点の大きいもの ほど革新的，小さいものほど保守的となる.

第 1 軸に第 1 因子，第 2 蟿に第 2 因子をとり，各因子 得点から学年別平均值を計算し図示したのが Fig. 4 で ある。この図によって，知識と態度の関係を調べること にする、まず, 学年ごとの平均值の位圆は $\mathrm{J}$ 字形を右ま わりに活ば 45 度回転した形のう充にあことがわかる。 高校 1 年は，このJ字形のうえにはあるが，高校 3 年に 近接した位置にあって登達的順序からずれているので, まずこれを除外して全体をみてみると，中学 3 年は，J 字形の左端にあり, 政治的知識は低く, かつ, 政治的態 度はニュートラルで，未だ構造化されていないことを想 像させる. 保守また革新への志向はみられない，高校 2 年になると，政治的知識はほとんど変らないが，急速な 保守化がみられる. この保守化の原因についてはさまざ まな外的要因がありらるが，推測の域を出ない。

さて，高校 3 年になると知識が飛踓的にら元，態度は 保守性を減じる。これ以後, 知識と態度はほぼ直線関係 にあり，知識ののびにつれて態度が革新化する.大学 1 年では, 態度のレベルは中学 3 年と变らないが，態度の 内容は構造化され，志向性をもっていると考えられる.

大学 2 年はJ字形の頂点に位置する。知識はさらに増 して最大となり，同時に態度は最も革新化する. 大学 3

- 4 年は, 知識も, 革新の度合も減じ, J 字形を逆もど りして下降し, 大学 1 年と 2 年の間に位置している。

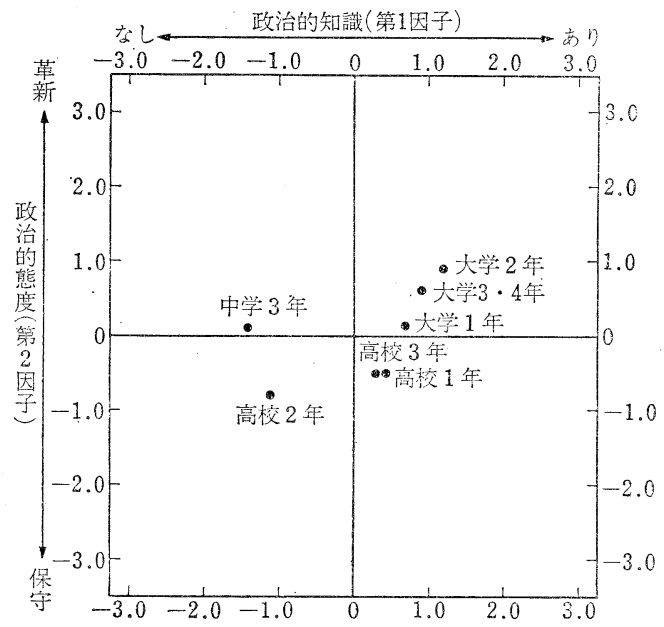

FIG. 4. 因子得点より計算した学年別平均值の位置
ここで，これまで除外してきた高校 1 年について考え てみよう。他の学年との位置関係だけからみれば, 隣接 する学年（中学 3 年, 高校 2 年) から離れ, 特異な位置 にあるよらにみえるが，重要なことは，この学年もJ字 形のうえにめって, 知識と態度の一定の関係を浀たして いることである.

\section{結果正 発達差を除いたときの政治的知識と政治的態度 の関連}

Fig. 5 は全変動の主軸解, 学年差を除いた变動の主軸 解, 学年差による变動の主軸解それぞれの固有值の動き を図示したものである，この図をみると，全変動の第 1 因子，第 2 因子の固有值は，学年差を除いた変動および 学年差による変動の第 1 , 第 2 因子の固有値をそれぞれ 加えたものにほ洼しく, 全変動と学年差を除いた変動 の固有値の差は第 3 因子以降小さくなり，2つの固有值 の大きさは，第 5 因子以降一致することがわかる.

学年差学除いた変動の因子分析の固有值の動きをみる と, 第 3 因子以降, 順次の固有値の大ささの差が, 急速 に小さくなるので，因子数を 2 とさだめ， 2 因子による バリマックス回転を㓡こない，因子負荷量をだしたのが Table 5 である. この表を見ると, 第 1 因子は変動の $26.3 \%$ を説明し, 因子負荷は知識尺度で低く, 態度尺 度で一貫して高い。これは態度因子である，第 2 因子は 説明率 $23.4 \%$ で, 因子負荷は知識尺度で総体的に高く, 態度尺度で低い．これは知識因子ということができる。

Table 4 とくらべると, 態度因子と知識因子の抽出順 序は異なるが，発達差をとり除くことによって，全体を 発達段階とは無関係に均質化した後も,な招, 態度因子 と知識因子が抽出されたことは重要である.

発達差と, 知識叔よび態度尺度との関係を Table 6 に

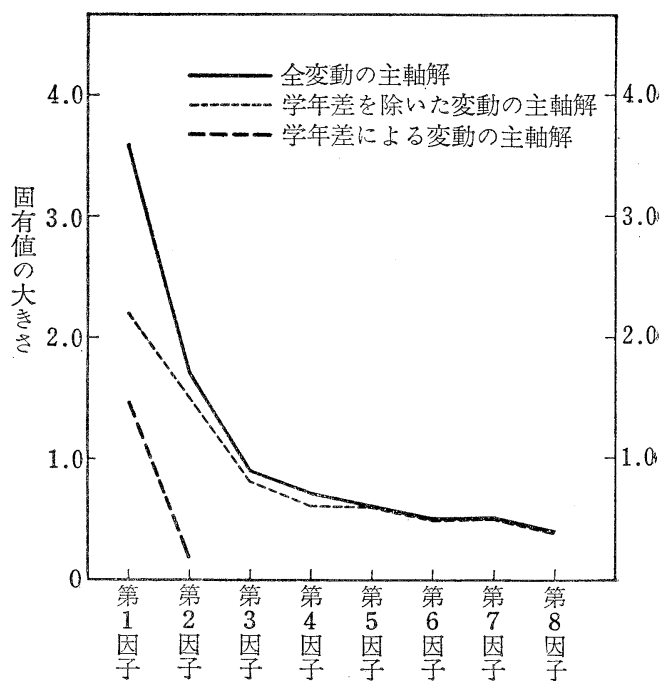

FIG. 5. 各主軸解による固有值のうごき 
TABLE 5

学年差を除いた 9 尺度を因子分析したときの因子負荷量 （主軸解の後バリマックス回転）

\begin{tabular}{|c|c|c|c|}
\hline & $\begin{array}{l}\text { 第 } 1 \\
\text { 因子 }\end{array}$ & $\begin{array}{ll}\text { 第 } & 2 \\
\text { 因 }\end{array}$ \\
\hline \multirow{3}{*}{ 知 } & 保・自 & 0.084 & 0.552 \\
\hline & 憲 法・学働運動・沖繩間 題 & 0.005 & 0.546 \\
\hline & 日 本 の 経 済・政 治・外 交 & 0.129 & 0.576 \\
\hline \multirow[t]{3}{*}{ 戥 } & アメリカ の 政 治・経 & 0.049 & 0.652 \\
\hline & アメリカの軍 事・外 & 0.094 & 0.571 \\
\hline & 安 保・自 衛 隊・軍国主義 & 0.703 & 0.095 \\
\hline 態 & アメリカの政治・経済・軍事・外交 & 0.776 & 0.097 \\
\hline \multirow{2}{*}{ 度 } & 日本 の 政 治・経 済・外 交 & 0.451 & -0.045 \\
\hline & 沖 繩 問 題 - 平 和 運 動 & 0.760 & 0.022 \\
\hline \multicolumn{2}{|c|}{ 固 } & 1.911 & 1.706 \\
\hline \multicolumn{2}{|c|}{ 説 } & 0.263 & 0.234 \\
\hline \multicolumn{2}{|c|}{ 累 } & 0.263 & 0.496 \\
\hline
\end{tabular}

よって検討してみよう。この表は，学年差による変動を 主軸法によって因子分析したときの, 因子負荷量を示し たものである、第 2 因子は，固有值の大きさからも，説 明率の低さからも, 無視しらるので, 第 1 因子をるっ て，発達因子と呼ぶことができる。主軸法で計算したた めか, 因子負荷量は, 全般的に大きく, 単純構造を示し てはいないが,このなかで，態度尺度の“沖繩問題・平 和運動”だは，小さくなっている，以上のことから， この尺度は，登達差を弁別するのに有効ではないこと， つまり，発達段階の違いが尺度得点上に反映されること のすくないことがるる。

\section{考察}

政治意識には，大別すると，個人の社会化過程の比較 的早い時期にわりあい安定し，それ以後の変化があまり 激しくないと考光られるものと, 社会化の進行につれて 変化し, 遅れて安定するものの 2 種類がある。前者の例 としては, 政党支持態度のよらに生涯を通じて変りにく いものがあげられ，後者の例としては，政治関心や政治 志向のように, 個人の発達と時代の状況につれて変化し やすいるのがあげられる. (Sears, 1969)

アメリカの高校上級生の調查では, 彼らが, その両親 よりもリベラルであり, 政治的シニシズムも少ないこと がみいだされている (Jennings \& Niemis, 1968). また， 大学生の調查では，彼らの大部分が，自分自身を両親よ り革新的と考えている (Sears, 1969). これは，青年が 草新的であること，年をとるにしたがって保守化するこ とを暗示している. そして，この変化はかなりドラステ ィックなものと考觉られる.
TABLE 6

学年差による変動を因子分析したときの因子負荷量 (主 朝 解)

\begin{tabular}{|c|c|c|c|}
\hline & & $\begin{array}{l}\text { 第 } 1 \\
\text { 因子 }\end{array}$ & $\begin{array}{ll}\text { 第 } & 2 \\
\text { 界 }\end{array}$ \\
\hline & 保・自 & 0.416 & -0.129 \\
\hline 知 & 憲 法・労働運動・沖繩 問題 & 0.448 & -0.098 \\
\hline & 日本 の 経 済・政 治・外 交 & 0.504 & 0.073 \\
\hline 識 & 力 の 政 治 - 経 & 0.466 & -0.187 \\
\hline & アメリカの央事・外 & 0.395 & -0.136 \\
\hline & 安 保・自 衛 隊・軍 国 主 義 & 0.480 & 0.175 \\
\hline 㤻 & アメリカの政治・経済・軍事・外交 & 0.406 & 0.188 \\
\hline & 日 本 の 政 治・経 済・外 交 & 0.285 & 0.134 \\
\hline & 沖 緋 問 題・平 和 運 動 & 0.047 & 0.065 \\
\hline & 有 & 1. 481 & 0.173 \\
\hline & 率 & 0.870 & 0.102 \\
\hline & 積 & 0.870 & 0.972 \\
\hline
\end{tabular}

本研䇴では，政治志向の 2 つの成分である. 政治的知 識と政治的態度が，線型関係からいえば互いに独立であ るが, 個人の発達段階に応じて, 一定のパターンをもっ て，構造化されていることが示された，ただ，残念なこ とに，政治的知識の質問項目が羅列的な知識をきくにと どまり，知識の統合体である知性にまで及ぶことがで きなかった，この点は，さらに検討してみる必要があ る.

Hyman (1959) は“政府は鉄道をコントロールすべき ですか”“鉱業や工業は国有化すべきですか”“歷史は本

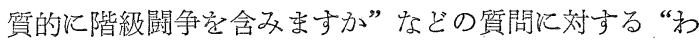
からない (don't know)”“決めか叔る (undecided)” といら回答や，イデオロギー尺度上の“どららとるいえ ない (indeterminate)”といら反応をもって, 政治志向 の欠如の指標とし，この指標が，年令とともに漸減する のをみて，政治志向が成長にともなって形成されると結 論している、しかし，第1に，はじめにるれたように， 知識成分と態度成分とを, あいまいなまま, 一体として めつかったため, 分析の対象が不分明となってしまっ た。第 2 に, 彼の政治志向のとら方方根底には, 個人 以政治的社会化の過程で, 政治志向を一方向にのみ構造 化させるといら考光方が㐫るため，本研究で示された， 大学 $3 \cdot 4$ 年のグループが，これまで政治的社会化の過 程でたどってきた道程を逆行するような現象を説明でき ない.

ここで，Fig. 4 に示された結果の意味を，すこし考光 てみよう，政治志向の推移を考えるためのさまざまな観 点がある、前にあげた知識欲なぞ，内的な要因を重視す ることる可能であるし，また，個人の発達にとるなって 
形成される, 準拠集団とこれからの影響力など, 外的要 因を重視することる可能であろう。しかし，これと同時 に，制度的な制約も度外視でさない，つまり，政治志向 の推移は, 公教育システムに和ける。政治的な“教化”

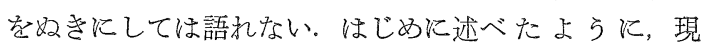
在, わが国の公教育は, 中学以上では, 中学 3 年之, 高 校 3 年で, 政治的社会化を促す教育を, 颃こなってい る.このような, 教育が, ひとつの起動力となって, 政 治志向が動くわけだが, 中学 3 年頃から, 高校 2 年頃 では，自分自身の碇泊点と方向性をるたないため，政治 志向は，大いにゆれ動くと考兄られる。しか，この動 きは，不規則なるのではなく，一定のパターンをもって いるが，そのようなパターンを生起させている原因を糺 明することは，ここでは，できなかった。

ともあれ，高校 3 年になると，政治志向の方向づけ が，完了するようである。

高校までの政治教育が，主として，中立的立場からの 教育を命ぜられている教師の側から招こなわれているこ と, 大学に大ると, 教師も自由に, 政治的意見や思想 述べるし，大学生の多くは，何らかのかたちで，“革新 的は良いことだ”“革新的たるべきだ”といった集団規 範をるった準拠集団とかかわりをもつようになり，学友 からの強い政治学習が特こなわれることを考光ると，高 校に和ける政治教育の反動形成として，大学 $1 \cdot 2$ 年を とらえることができるだろう。

大学 $3 \cdot 4$ 年で, 政治志向の逆行がみられるが, この 点に, 若干の考察を加えてみよう。どの国にあっても, 大学生は，もっとも自由な生活を和くることができるわ けだが，同時に，その国の特殊な制度，習慣の影響も受 けている。わが国では，〈結果>でも，られたように， 大学 $3 \cdot 4$ 年生は, 半社会人であり, 目の前に, 就職の 壁が，そして，彼らのなかには，人よりも，ぬさんでよ うとする立身出世主義がある。いき特い，良い成績を特 さめて，良い就職をすることに汲々として，社会的・政 治的視野が，せばるっていく，大学紛争に和ける. $1 \cdot 2$ 年生と $3 \cdot 4$ 年生の役割の違いるみ机ば，この間の事情 がわかる。

Newcomb (1943) のベニングトン大学に和ける研究 では, 大学生は上級生になるほそ，保守性を減じること が指摘されている。この場合，日米の大学生をとりかこ む political culture の差は㐫きらかである.アメリカ では, Newcomb (1943) が述べているように，一般に， 大学上級生でさ光, “急進的”と呼ぶことはできない。 また，大学教育を受けた人は，受㐨なかった人にくらべ て, やや保守的でさ光ある。したがって，アメリカに稀 いて大学生は, かりに, 大学生以外の人々とくらべて保 守性が弱いとしても，革新的ではなく，アメリカの政治 風土のなかでは, 大学生活は, 個人に在学年数に応じ
て，保守性を減じるような力を与えることはあっても， その力は弱く, 卒業とともに, 所属階層や集団の影響の もとに, 再び容易に保守化する.

日本に和いては, 事情が若干異なっている。大学 $1 \cdot 2$ 年生の急進化と, 大学 $3 \cdot 4$ 年生にその萠芽を見せ, 卒 業後顕著となる急進性の減退は, よりドラスティックで

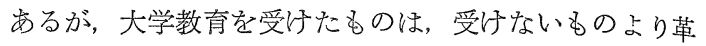
新的でありつつける。つ京り, 日本に打ける大学教育 は，個人に，保守化をさまたげる準拠枠組を提供してい ると考えることができるだろう．

次に，発達差をとらえる道具の間題を考えてみよう。 態度尺度には，発達差を弁別できるものと，でさないも のとがある。すなわち，4つの態度尺度のうち 3 つまで は，発達差を弁別できるが，沖繩問題・平和運動尺度 は，発達差を弁別できない（Table 6)。この相違をうみ だした理由は，この沖繩問題・平和運動尺度の信頼性に 問題があったためである.この尺度を構成する 5 変数の うち, “核兵器残留での沖繩返還”をのぞく 4 変数につい ては, 分散が小さく, 平均が革新側に寄っていて, 反応 傾向が固定している.つまり，定形的パターンがある。 このため $\alpha$ 係数は, 0.466 と低く, 尺度内変数の因子負 荷にも, かなり小さなるのが多い, つまり, 尺度の精度 は, かなり低いと文られるわけである。この尺度は, 発 達的変動を、すくいあげることができなかったと教えら れる。

政治志向は流動的であり，固着しにくいであろうが， 一度獲得された政治志向は，一定の準拠枠組としての機 能をもつであららから, 年をとるにつれて社会化の退行 が起こるといっても，無制限なるのではないであろう. この間の関係を確定するためには, 対象者の年令のはば を、さらに広げた調查研究が必要であらう。

なた, 政治的社会化の機関, とくに, 学校に和ける政 治教育がもたらす影響力について,もっと詳細に吟味す る必要があるが，これも，今後の研究課題のひとつであ る.

最後に, 本研究で得られた知見を一般化する際の制限 条件として, 調査対象者の問題にふれておこう。著者ら は大学生との連続性をるとめる意味で, 中学・高校生を 県下のいわゆる一流校からとり, 同一人を何年にもわた って観察するのと類似の条件を得ようとこころみた。 こ の点については評価されるべきであろらが，そのため， 調査が，ある種のエリート調㚗になったことも事実で ある、したがって, 本研品結果は, 厳密には, このエ リート層にのみあてはまるということになる。

一般人の政治的社会化過程に掠ける, 政治志向につい て知るためには，テンダムサンプリングに基づいた，多 くの対象者についての調査研究が必要である。これもま た，今後の課題である. 


\section{要約}

本研究の目的は，政治志向の主成分である政治的知識 と政治的態度とが互いに, 政治的社会化の過程のなかで, どのような関連をもっているか吟味することにあった。

長野県下の中学 3 年から, 大学 4 年索での合計 543 名 の対象者に質問紙による調查を行ない，政治的知識につ いて 5 尺度, 政治的態度について 4 尺度の尺度を構成し, この合計 9 尺度を因子分析したところ, 知識因子 $((+)$ 㐫り一なし (-)）と態度因子 $((+)$ 革新一保守 $(-))$ が 抽出された。

この 2 因子の因子得点から，各学年別に平均值をもと め, 2 次元座標上にプロットしたところ，各学年は，ほ 弫字形の上に位置することがわかった。

中学 3 年は $\mathrm{J}$ 字形の左端にあり, 政治的知識は低く, 政治的態度は未分化. 高校 2 年になると, 政治的知識は ら劣ているにるかかわらず，急速に保守化する．高校 3 年では知識が飛躍的に増し, 保守性を減じる. これ以後, 知識と態度は活ぼ直線関係にあり，大学 2 年は，J字形 の頂点に位置する. 大学 $3 \cdot 4$ 年になると, 知識す革新 の度合いる減じ, J 字形を逆もどりして, 大学 1 年と 2 年の間位置する.

発達差を除いて, 全体登均質化した後, 因子分析を行 なったところ，ふたたび知識因子と態度因子が抽出さ れ，政治志向の因子構造は発達段階の影響を受けないこ とが示された。

\section{知識に関する項目}

\section{附表 調 查 項 目}

（1）安保・自衛隊㳊関する質問

1) 日米安保条約がはじめて結ばれたのは：ア。昭和 20 年 イ。昭和 26 年 ウ。昭和 35 年 エ。わからない

2）々の時の首相は：ア。幣原首相イ。吉田首相 ウ、岸首相工。おからない

3）自動延長というのは, 次の5らどれに関係があり ますか：ア。米価イ。国会吕、日米安保条約工。 わからない

4）自衛隊の指揮権をもっているのは：ア．天皇 イ。 内閣総理大臣 ウ。防衛庁長官工。わからない

5）防衛庁長官は:ア. 田中角栄イ。增田甲子七 ウ。中曾根康弘工。わからない

6) 四次防五力年計画は何年度から始まり委すか： ア. 1972 年イ. 1975 年ウ. 1978 年エ。わからない

（2）憲法・労働遺動・沖繩に関する質問

1）日本国憲法第九条には，ぞういう事が書いてあり ますか：ア、主権は国民にあるイ、天皇は日本国の象 徵であるウ。戦争放棄工。わからない

2）総評というのは，ぞれに関係がありますか：ア。

国会1、学働組合ウ、貿易工。わからない

3）沖繩が返還されるのは：ア.1971 年 イ.1972 年 ウ. 1973 年 エ。わからない
4）“核过本土並返還”といっているのは：ア．自 民党 イ、社会党 ウ。民社党 エ。わからない

5）潜在主権というのは，次のうちどれに関係めると 思いますか：ア。天皇 イ。国民币、沖繩工、わか らない

6）沖繩の人口は，大体：ア. 50 万イ. 100 万ウ。 150 万工。わからない

（3）日本の政治・経済・外交に関与る質問

1）非武装中立といっているのは：ア．社会党 イ。 民社党 ウ。共産党 エ。わからない

2）日本は，国民総生産で世界第何位ですか：ア．7 位 イ. 5 位 ウ. 3 位工。わからない

3）日本の一人あたり国民所得は，世界第何位です か：ア。11位イ。16 位ウ。 21 位工。わからない

4) 大蔵大臣は：ア。鈴木善幸 イ。三木武夫ウ。 福田起夫工。わからない

5） $3 \mathrm{C}$ というの, カ一, カラーテレビと何ですか: ア.カメライ、クーラーウ。キャビンエ。わから ない

6)経団連というのは, 何の略称ですか：ア．経済団 体連合イ. 経国団結連盟ウ. 経営団体連盟工。 からない

7）所得倍增政策をとったのは：ア．岸首相イ。池 田首相 ウ。佐藤首相工。わからない

8）“自ら国を守る気概を持て”と言ったのは：ア。 ニクソン大統領イ。无皇陛下ウ. 佐藤首相工。わ からない

9）日本の外務大臣は：ア．佐藤一郎て。藤山愛一 郎ウ。愛知撥一工。わからない

（4）アメリカの政治・経済に関する質問

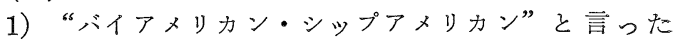
のは：ア・ケネディ大統領イ・ジョンソン大統領 ウ。 ニクソン大統領 エ。わからない

2）黑人の公民権運動飞関係学る人は：アキキング イ、リンカーンウ、ワシントンエ。わからない

3）グアムドクトリンというのは，どういう政策を決 めたるのですか：ア。沖繩返還政策イ・アジアへの軍 事介入をへらす政策 ウ。中国の国連加盟を阻止する政 策工。わからない

4) アメリカの大統領は：ア.レアードイ、ロジャ ースウ。ニクソンエ。わからない

5）アメリカの二大政党とは民主党と何ですか：ア. 学㗢党イ。共和党 ウ。キリス卜教民主同盟工。わ からない

6）貿易の自由化に関係が岁るのは：ア，GATTイ。 ILO ウ. WHO 工。わからない

（5）アメリカの軍事・外交に関する質間

1）第七艦隊というのは, どこの国の艦隊ですか： ア、イギリスイ、アメリカウ・ソヴィエットエ。 わからない

2）新孤立主義外交とよばれるのは，ぞこの国の外交 ですか：ア、アメリカイ、中国ウ・スイスエ、わ からない 
3）ヴェトナム化政策といわれるのは，次のうちどれ 《あてはまりますか：ア，ヴェトナムを統一する政策 イ、ヴェトナム戦争をやめさせる政筑 ウ，ヴェトナム 人だけで戦争させる政策 エ。わからない

4）駐日アメリカ大使は：ア．マイヤーイ、ライシ ヤワーウ、ジョンソンエ。わからない

5）“アジア安保”と言われるのは，ぞういう事でし ようか：ア．アジア諸国が安保条約を結ぶことイ。日 米安保条約の適用範团がアジアに及ぶことウウ日本と 中国が安保条約を結ぶこと土。わからない

\section{態度に関する項目}

（1）安保・自衛隊に関する質間

1）ある人が “日本が独立と平和を守っているのは， 日米安保条約の括かげだ”と言ったらあなたは、この意 見愎成しますか，とれとも反対しますか：ア．非常に 賛成するイ、どちらかといえば賛成する ウ。どちら

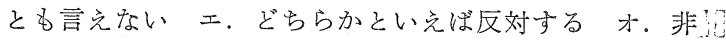
常に反対する

2）安る人が “日米安保条約は，世界の平和㪀立っ ている”といったらあなたはこの意見に賛成しますか, 反対し未すか：ア．非常に賛成する イ。どちらかとい

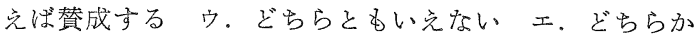
といえば反対であるオ。非常に反対する（以下同じよ うな方法で答えて下さい)

3）㐫る人が“自衛隊は，憲法違反だ”と言ったら： （解答方法は 1)，2）同様）

4）ある人が“自衛隊は，もっと強くすべきだ”と言 ったら：

5）ある人が“戦争になったらアメリカは，日本を守 ってくれる”と言ったら：

6）昰る人が“日米安保条約は，共産主義諸国宥威 を与劣ている”と言ったら：

7）あなたは日米安保条約について：

（2）アメリカの軍事・外交に関する質問

1）せる人が“アメリカ軍は，全部ヴェトナムから撤 退するだろら”と言ったら：

2)㐫る人がアメリカは，外国援助をへらすだろう” そ言ったら：

3）岁人が“アメリカは, アジアやヨーロッパから 軍䧩を引きあげた方が良い”と言ったら：

4）ある人が“ヴェトナム戦争でアメリカは負けたの だと言ったら：

5）ヴェトナム戦争について，出なたは：

（3）アメリカの政治・経済に関する質間

1）昰る人が“アメリカは，保謢貿易政策をとってい る”と言ったら：

2）ある人が“アメリカは，今，経済的に大变困って いる”といったら：

（4）日本の政治・経済・外交に関する質問

1）ある人が “日本は, 共産主義諸国とも平和条約を 結ぶべきだ”といったら：

2）ある人が“日本は，もっと経済的に成長しなけれ ばならない”と言ったら：
3）㐫る人が“日本が，経済的に伸びたのは政治が良 かったからだと言ったら：

4）ある人が“日本が，経済的に伸びたのは国民が勤 勉だからだと言ったら：

5）㐫る人が“日本が，経済的に伸びたのは労働者の 生活をぎせいにしたからだ”と言ったら:

6）劣る人が“日本が経済的に伸びたのは軍事予算を 最小限にとどめたためだと言ったら：

7）㐫る人が“日本が，経済的に伸びたのは教育水準 が高いからだ゙と言ったら：

8）ある人が“日本の企業は，るっと東南アジアへ進 出すべきだと言ったら：

9）ある人が“日本は，貿易を自由化すべきだ”と言 ったら：

10）ある人が“日本は経済大国である”と言ったら：

11）学るが“日本経済は，将来行きづまるだろう” と言ったら：

12）ある人が“日本は，日本独自の外交政策をとるべ きである”と言ったら：

（5）沖繩・学働運動・平和運動・その他に関する質問

1）劣るが “黑人が公民権学要求するのは当然だ” と言ったら：

2）岕る人が“アメリカでは, 反戦運動はもっとたか まるだろら”と言ったら：

3）ある人が“アメリカは，平和な国だ”と言ったら：

4）沖繩返還されることについてめる人が“アメリカ 軍の核兵器を残した末束, 沖繩は返還される”と言った ら:

（6）日本の軍国主義に関する質問

1）岁人が“太平洋戦争で日本は, 東南アジア諸国 の独立を助けた”といったら：

2）出る人が“日本は，侵略される阷それがある”と 言ったら:

3）亦る人が “日本でも，将来徴兵制がしかれるだろ ろ”と言ったら：

4）ある人が“日本は，小型核兵器ならば持つことは できる”と言ったら：

5）岁る人が“日本も，核兵器をもつべきだと言っ たら :

6）岕人が“日本は，アジアの指導者である”と言 ったら：

7）ある人が“日本は，軍国主義にもどった”と言っ たら:

8）岕る人が“若者は，天皇赏愛し，尊敬する心をる たなければならない”と言ったら：

9）ある人が“自分の国土は，自分達で守る心゙きだ” そ言ったら：

\section{引用 文 献}

Easton, D., \& Hess, R. D. 1961 Youth and the political system. In Seymour Martin Lipset \& Leo Lowenthal (Eds.) Culture and social character. New York: The Free press, Pp. $226-251$. 
Greenstein, F. I. 1968 Political socialization, International encyclopaedia of the social sciences. New York: Macmillan \& Free Press Pp. $551-555$.

広瀬弘忠 1971 政党支持之政治関心の構造分析 心研 42, 175-184.

Horst, P. 1965 Factor analysis of data matrices. New York: Holt, Rinehart \& Winston.

Hyman, H.H. 1959 Political socialization: A study in the Psychology of political behavior. New York: The Free Press.

Jennings, M. K., \& Niemis, R.G. 1968 The transmission of political values from parent to child. Amer. polit. Sci. Res., 62, 169-184.

Lord, F. M., \& Novic, M.R. 1968 Statistical theories of mental test scores. Reading Massachusetts : Addison-Wesley.

直井道子 1972 政治的社会化過程に掠ける集団の役割 社会学評論, $22,17-29$.
Newcomb, T. M. 1943 Personality and social change. New York: Dryden Press

岡村忠夫 - 相内俊一 - 北岡博章 - 崔 勝久 - 迫川由和 1969 政治的社会化飞拈ける<民主主義>と <平和> 社会科学ジャーナル, 8, 1-43.

Sears, D. O. 1969 Political behavior. In Gardner Linzey \& Elliot Aronson (Eds.) Handbook of social psychology. (2 nd ed.) Reading, Massachusetts : Addison-Wesley Vol. 5, P.p. $315-458$.

芝祐順 1972 因子分析法 東大出版

芝 祐順 1967 行動科学のための相関分析法 東大出版 Yanai, H. 1970 Factor analysis with external criteria : Application of analysis of variance and regression analysis technique to factor analysis. Jap. psychol. Res. 12, 143-153.

柳井晴夫 1969 分散分析的手法の因子分析への適用飞 ついて 教心研, 17, 1-12.

- 1972. 7. 5. 受稿—

\title{
RELATIONSHIPS BETWEEN POLITICAL KNOWLEDGE AND POLITICAL ATTITUDES IN THE PROCESS OF POLITICAL SOCIALIZATION
}

\author{
HIROTADA HIROSE \\ Institute of Journalism, University of Tokyo
}

\begin{abstract}
The purpose of the present study was to examine the relationships between political knowledge and political attitudes, which are the principal components of political orientation.

The questionnaire was administered to 543 male and female students in Nagano prefecture, ranging in age from the third year of junior high school to the senior year of college (113 third year junior high school students; 204 senior high school students, of whom 80,87 , and 37 were first, second and third year students, respectively; 226 college students, of whom 100,103, 13 and 10 were freshmen, sophomores, juniors and seniors in that order).

The questionnaire contained 32 items which were concerned with political knowledge and 40 items which were concerned with political
\end{abstract}

attitudes. Five knowledge scales were constructed from the 32 items regarding political knowledge : they were 1) US. Japan Security Pact-Japanese Self Defense Army scale, 2) Japanese Constitution-Labor MovementOkinawa Problem scale, 3) Japanese Politics -Economics-Diplomacy scale, 4) US Politics - Economics scale and 5) US MilitaryAffairsDiplomacy scale. From the 42 items regarding political attitude, four attitude scales were constructed : they were 1) US. Japan Security Pact-Japanese Self Defense Army-Japanese Militarism scale, 2) US Politics-EconomicsDiplomacy-Military Affairs scale, 3) Japanese Politics-Economics-Diplomacy scale and 4) Okinawa Problem-Peace Movement scale.

These nine scales were analyzed using principal factor analysis. The solution was varimax-rotated with two factors. It was found that the first factor was the knowledge 
factor (have $(+)$ - not have $(-)$ ) and the second factor was the attitude factor (progressive $(+)$ - conservative $(-))$. From these two factors, the means were calculated for each year and were plotted on two-dimensional plane; the abscissa for political knowledge, the ordinate for political attitude. The resulting curve was a $\mathrm{J}$-shaped one.

The third year students of junior high school had their position on the left end of the J-shaped curve. At this stage of development, the political knowledge was low and the political attitude was not well structured yet. For the second year students of high school, their mean political attitude score inclined to the conservative side, in spite of their increased political knowledge. Hereafter, both political knowledge and political attitudes changed rapidly from the stage of littleknowledge and conservative to one of greaterknowledge and radicalism in a nearly linear relationship. At the junior and senior year of college, both the degree of political knowledge and of progressivism reverted to levels between those of freshmen and sophomores.

Next, after removing statistically the effect of developmental difference and making the entire sample homogeneous, factor analysis was carried out again. The result was not substantially different from that of the above analysis; that is, both the political knowledge factor and the political attitude factor were extracted. From these results it was concluded that the factor structure of political orientation was not affected by the developmental stages of the individual. 